ljtihad: Jurnal Wacana Hukum Islam dan Kemanusiaan

Vol. 21, No. 1 (2021), pp. 79-97, doi : 10.18326/ijtihad.v21i1.79-97

\title{
Science-based Ijtihad: religious and scientific dialectic on fatwas regarding congregational worships amid the covid-19 pandemic
}

\author{
Ali Sodiqin \\ Universitas Islam Negeri (UIN) Sunan Kalijaga \\ ali.sodiqin@uin-suka.ac.id \\ DOI: 10.18326/ijtihad.v21i1.79-97
}

The covid-19 pandemic has impacted religious practices, including Islamic practices. Islamic scholars have issued several fatwas which regulate how congregational worships should be practiced. For instance, a fatwa regulates that a worship which is supposed to be performed at a mosque collectively should be performed at home individually. The rapid spread of coronavirus becomes the primary reason for issuing this regulation. This study is a normative study which employs an usul fikih approach. The object of the study is the religious and scientific dialectic on fatwas regarding congregational worships amid the covid-19 pandemic. Data is collected by gathering fatwas issued by ulama councils around the world. The data is analyzed through a ta'thy logic, that is a logical reasoning that is based on 'illah (reason). This study is built upon the theory of istibsan bil maslahah, which refers to a theory about how Islamic laws can change depending on their benefits. This study presents three main findings. First, in issuing fatwas regarding the covid-19, ulama used scientific findings about the danger of coronavirus as 'illah for changing the practice of congregational worships and employed as a lens to consider the benefit of a law. These ulama used the interrelationship model of interests (maslabab) in which preserving of soul (bifzan-nafs) was more important that preserving of faith (bifzad-dîn). Second, the ulama methodologically combined religious method, which was based on interpretative approach, and scientific method, which was based on empirical approach. This integration of religious and scientific methods reflected doctrinal-philosophical aspect and legalethic aspect of the fatwas. Third, the fatwas indicated the use of functional interpretative approach towards scriptural texts, logic, and reality. 
Pandemi covid-19 berakibat langsung terhadap perubahan pelaksanaan ajaran agama, termasuk di dalamnya agama Islam. Melalui fatwa, para ulama menetapkan perubahan hukum pelaksanaan ibadah secara kolektif. Ibadah yang seharusnya dilaksanakan di masjid dialihkan ke rumah dan hukum melakukannya yang semula wajib berubah menjadi terlarang. Bahaya penyebaran coronavirus yang cepat dan mematikan menjadi dasar dan alasan perubahan hukum pelaksanaan ibadah. Jenis penelitian ini adalah penelitian normatif dengan menggunakan pendekatan usul fikih. Objek kajiannya adalah relasi agama dan sains dalam fatwa-fatwa tentang pelaksanaan ibadah secara berjamaah pada masa pandemic covid-19. Data penelitian diperoleh dari fatwa-fatwa yang dikeluarkan oleh lembaga ulama di dunia Islam dari berbagai benua. Analisisnya menggunakan penalaran ta'lihy, yaitu penalaran yang berbasis pada illat hukum. Teori yang digunakan adalah istihsan, yaitu teori perubahan hukum Islam, khususnya istiḥsân bil maslaḥah. Hasil temuan penelitian ini adalah: pertama, dalam fatwa-fatwa tentang covid-19, temuan sains tentang bahaya coronavirus menjadi illah perubahan hukum bagi pelaksanaan ibadah yang dilakukan secara berjamaah dan sebagai alat pengukur kemaslahatan hukum. Para perumus fatwa menggunakan model interkoneksi antar maslahah, sehingga perlindungan nyawa (bif.̧, an-nafs) didahulukan atas perlindungan agama (bif za ad-dîn). Kedua, secara metodologis ulama memadukan antara metode agama yang berbasis penafsiran dengan metode sains yang berbasis pengamatan, sehingga terjadi integrasi agama dan sains dalam aspek doktrinal-filosofis dan legaletis. Ketiga, hukum yang dirumuskan dalam fatwa-fatwa tersebut menunjukkan adanya penggunaan model paradigma penafsiran fungsional terhadap wahyu, akal, dan realitas.

Keywords: scriptural texts and logic; fatwas; covid-19; congregational worships

\section{Introduction}

The covid-19 pandemic has impacted not only health and economic aspects but also religious aspect in terms of how religious practices take place. One of these religious practices is congregational worship, where it is performed individually or virtually instead of collectively at a mosque (Parish, 2020). It is feared that a congregational worship at a mosque can cause the spread of coronavirus. This situation in turns requires the reconceptualization of existing religious laws in respond to such religious practice.

Studies about the covid-19 from the Islamic perspective include such topic as: the effect of the covid-19 to the practice of umrah in Mecca (Ebrahim \& Memish, 2020), spiritual healing in overcoming the pandemic (Indriya, 2020), controlling the pandemic as stated in the Hadith (Qudsy \& Sholahuddin, 2020), and the progressive fatwa issued by Indonesian Ulama Council/Majelis Ulama Indonesia (MUI) regarding the covid-19 (Sholeh, 2020). In a different focus, this study delves into analyzing the dialectic between religion and science with regard to the fatwas issued amid the covid-19 pandemic. 
The rapid spread of coronavirus has caused ulama to issue fatwas that change the way Muslims practice worships. These fatwas are considerably global as these are issued by ulama councils around the world (MUI, 2020; Sabary, 2020), use similar method and source, and result in a similar decision - prohibiting congregational worships at mosques, including the Friday prayer. The restriction policy is taken due to the spread of coronavirus which according to scientists can harm people's lives (Hamid, S., Mir \& Rohela, 2020). As such, the ulama inevitably refer to scientific reasoning as the basis of their fatwas. This, from the methodological perspective, raises a question on the validity of how the fatwas are issued.

From the epistemological point of view, human's logic is an essential aspect when deciding Islamic laws. Meanwhile, according to the principles of Islamic jurisprudence, human's logic, which becomes the source of science, is considered as the source and method for deciding laws (Az-Zuhaili, 2013). It can be said that when deciding Islamic laws, divine aspect and human aspect should be both considered. In the fatwas related to the covid-19, ulama attempt to integrate religious values and scientific values. As such, it is important to investigate the integration model that has been used, how the ulama describe the divine and human aspects in their fatwas.

In Islamic jurisprudence, there is a principle that discusses how a fatwa can change due to the changing contexts where the fatwa is enforced. This principle is the rationale for the flexibility, dynamic, and plurality of Islamic jurisprudence (Hallaq, 2009). In the context of fatwas regarding the covid-19, there have been several changes of laws that are based on scientific findings. In particular, the danger and the rapid spread of coronavirus as explained by scientists become the basis for reconceptualizing laws with regard to congregational worships. For instance, performing prayers collectively at a mosque is no longer recommended but it is restricted; Friday prayer at a mosque is no longer obligatory but it is also restricted. In this restriction, coronavirus is considered as the main inhibitor of congregational worships. This restriction attempt indicates the progressiveness of Islamic methodology in which science is closely considered when determining a law. As such, a comprehensive study is needed to validate the extent to which science becomes an important aspect in Islamic laws. 
Ijtihad: Jurnal Wacana Hukum Islam dan Kemanusiaan, Volume 21, No. 1, Juni 2021: 79-97

This study is aimed at exploring the rationale for revising the laws related to congregational worships amid the covid-19 as reflected in the fatwas issued by ulama councils around the world. Additionally, this study attempts to mitigate the model used by the ulama in combining religious values and scientific values. Lastly, this study seeks to explain the ulama's interpretative paradigm in integrating scriptural texts, logic, and reality.

\section{Methodology}

This study is a literature study in which the fatwas regarding congregational worships amid the covid-19 are the object of the study. This study employs an usul fikih approach where the methods used by ulama councils around the world in making decisions are closely investigated. The focus of this investigation is on the relationship between logic and scriptural texts. The collected data are analyzed through a ta'lily logic, that is a logical reasoning that is based on 'illah (reason). The theory used as a lens to view the fatwas is istihsan, a theory about how Islamic laws can be revised. Based on this theory, it is said that laws that are based on nas (texts) can be revised if there is a robust 'illah. More particularly, the revision is based on several reasons such as the nas is revised by another nas, ijma (consensus), 'urf (custom), darurah (necessity), qiyas (analogical reasoning), and maslahah (public interests) (Az-Zuhaili, 2013). The validity of 'illah in the fatwas is explained through a functional interpretative paradigm (Mustaqim, 2010). This paradigm considers scriptural texts, logic, and reality as having a functional relationship instead of a structural relationship. In other words, this paradigm tries to capture the dialectic between scriptural texts, logic, and reality.

Interests which becomes the rationale of the fatwas is analyzed through the interrelationship concept of maslahah (Tahir, 2015). Five basic protections (usul al-khamsah) in the objectives of Islamic law (maqâsid sharîab) which include preserving of faith (bif

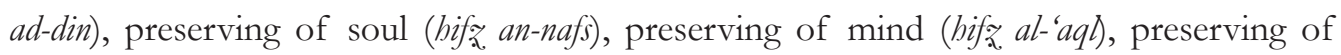
offspring (bifzan-nash), and preserving of wealth (bifzal-mal) are considered as integrated and interconnected to one another. In this study, the analysis on the interrelationship of maslahah focuses on three aspects, which are scriptural texts, reality, and subject of the law (Tahir, 2015). 


\section{Science and the authority of logic in Islamic laws}

Science and religion are two entities that are different in many aspects such as in their ontological aspect, epistemological aspect, and axiological aspect. Ontologically, religion is often related to immaterial aspects of life, while science usually discusses material aspects of life. Epistemologically, religious truth is based upon the God's authority, while scientific truth is based upon empirical observations or findings. From the axiological aspect, religion is aimed for a personal transformation, while science refers to knowledge that is used for the benefit of mankind (Bagir, 2005). These differences seem to always position religion and science in two opposing poles, in which according to Barbour (2002) can be found in at least three typologies, namely: conflict, independency, dialogue, and integration. In different typologies, Haught (2004) divides these differences into conflict, contrast, contact, and confirmation. These typologies apply to all religions in which the relationship between religion and science is always reciprocal and dynamic (Arion, 2018).

According to Rolston (1987), both science and religion view the world as something that can be understood logically, but these two depart from two distinct paradigms. To accommodate these two paradigms, a thinking model that encompasses independent discussions and dialogues with a specific attention on aspects such as subjectivity, objectivity, and inter-subjectivity is needed (Abdullah, 2014). These dialogues can be done scholastically, by employing interdisciplinary and multidisciplinary methods, and personally, by making dialogue between theologists and scientists through interpersonal collaborations (Sanda et al., 2017). As the conflict between religion and science is often based on rational against irrational arguments, it is necessary to examine the truth behind these two entities (Galadari, 2011).

The relationship between science and religion has been studied intensively in Islam. Form the epistemological aspect, Malkawi (2015) suggests the necessity to integrate religion and science into both productive and consumptive dimensions. The interconnection between the two needs to produce an integrated methodology, that is a methodology that combines observation methods and logical or intuitive methods (Arsyad, 2016). This interconnection model takes place in at least three domains, namely integrative-independent, integrativecomplement, and integrative-qualitative. These three domains can close the gap between 
Ijtihad: Jurnal Wacana Hukum Islam dan Kemanusiaan, Volume 21, No. 1, Juni 2021: 79-97

science and religion in terms of their formal object, method, and role (Mufid, 2014).

The consideration of science in Islamic laws faces methodological and ideological challenges (Al-Kahtani et al., 2015). However, it is thought that the integration of science will produce a more comprehensive legal decision in Islam (Baihaki, 2018). Particularly, scientific findings contribute to a more robust rationale when implementing an Islamic law (Syukriya \& Faridah, 2019). Guessoum (2014) suggests a quantum approach in analyzing the relationship between religion and science. This approach is based on a Quranic philosophy, that is humans are able to learn through their minds. The use of humans' minds in scrutinizing Quranic texts constructs knowledge ( $\mathrm{ilm}$ ) along with its methodology which in turn creates a hierarchical knowledge. In this case, scrutinizing Quranic texts is conducted through two levels, which are a general scrutiny, which can be understood by common Muslims, and an in-depth scrutiny, which can be accessed by scholars (Guessoum, 2014).

\section{Fatwas on the Covid-19 pandemic and their methodological problems}

Legal arguments regarding fatwas on the covid-19

Many ulama councils around the world have issued a similar fatwa that restricts Muslim in performing collective prayers at mosques amid the covid-19 pandemic. These include ulama council of Saudi Arabia, ulama council of Al-Azhar Egypt, the European Council for Fatwa and Research, Lajnah ad-Dâimah lil Iftâ fi Majmâ' Fuqahâ Amrîka asy-Shamâliyah (USA), Majlis al-'Ilmi al-A'â bi al-Maghrib (Marocco), Majmâ' al-Fiqhy al Irâqy li Kibâri alUlamâ li ad-Da'wah wa al-Iftâ (Iraq), Lajnah al Waz̧îiyah li al-Fatwâ biwuzârati asy-Syuni Diniyah wa al-Awqâf bi al-Jazâir (Algeria), ulama council of Kuwait, ulama council of United Arab Emirates, and ulama council of Indonesia. These councils are officials that have the authority to issue fatwas in each of their countries. Fatwas by these councils usually become important recommendations for the related governments in implementing laws regarding recent societal issues.

From the methodological point of view, fatwas regarding the covid-19 are in congruent with principles of Islamic jurisprudence, in which these fatwas are based on the Quran, Hadith, and other Islamic legal maxim. One of the monumental decisions in these fatwas is banning collective prayers at mosques, either the five-time prayers or the Friday prayer (Sabary, 2020). 
Ulama councils in Marocco, Algeria, and Saudi Arabia took a step further by suggesting their governments to close all mosques and ban Muslims for praying at designated public places. In addition, they also recommended that those who were infected or had been exposed to coronavirus were forbidden from entering mosques (Sabary, 2020). The main reason behind this restriction was the rapid spread of coronavirus and casualties caused by this virus. They particularly argued that mass gathering at mosques could make the spread of the virus faster and it was better to save lives than performing collective prayers at mosques (Sabary, 2020).

The 'harm' aspect of coronavirus is considered as khauf (worried) which becomes a legal argument for banning collective prayers (Sabary, 2020). Additionally, coronavirus also causes ḍarâr (emergency danger), where Muslims must avoid. Both khauf and ḍarâr are legal arguments that can be used to forsake certain laws. In this case, the objective of Islamic jurisprudence where saving lives is more important than performing congregational worships is emphasized. In the hierarchy of the objectives of Islamic jurisprudence, protecting lives is categorized in the highest level of daruriyah (necessities). Meanwhile, performing congregational worships is in the third level or takmilliyah (luxuries) (Sabary, 2020).

This study systematically presents legal decisions or fatwas issued by ulama councils around the world regarding the covid-19 in the following table.

Table 1. Fatwas regarding the covid-19

\begin{tabular}{|c|c|c|}
\hline Ulama Councils & Fatwas & Arguments \\
\hline Saudi Arabia & $\begin{array}{l}\text { Collective prayers at mosques } \\
\text { are suspended, and all mosques } \\
\text { are closed, the Friday prayer is } \\
\text { substituted with Dhuhr prayer, and } \\
\text { Pilgrimage is suspended for both } \\
\text { local visitors and foreign visitors }\end{array}$ & $\begin{array}{l}\text { The harm aspect of coronavirus } \\
\text { is considered as khauf (concern). } \\
\text { It is stated in scriptural texts } \\
\text { that harming oneself and others } \\
\text { is forbidden. }\end{array}$ \\
\hline Egypt & $\begin{array}{l}\text { Collective prayers at mosque } \\
\text { are suspended, all citizens must } \\
\text { comply with instructions from the } \\
\text { health authority. }\end{array}$ & $\begin{array}{l}\text { The danger of coronavirus } \\
\text { is real, a concern of getting } \\
\text { infected by the virus is a } \\
\text { valid reason for suspending } \\
\text { congregational worships at } \\
\text { mosques. }\end{array}$ \\
\hline
\end{tabular}


ljtihad: Jurnal Wacana Hukum Islam dan Kemanusiaan, Volume 21, No. 1, Juni 2021: 79-97

$\begin{array}{lll}\text { Ulama Councils } \quad \text { Fatwas } & \text { Arguments }\end{array}$

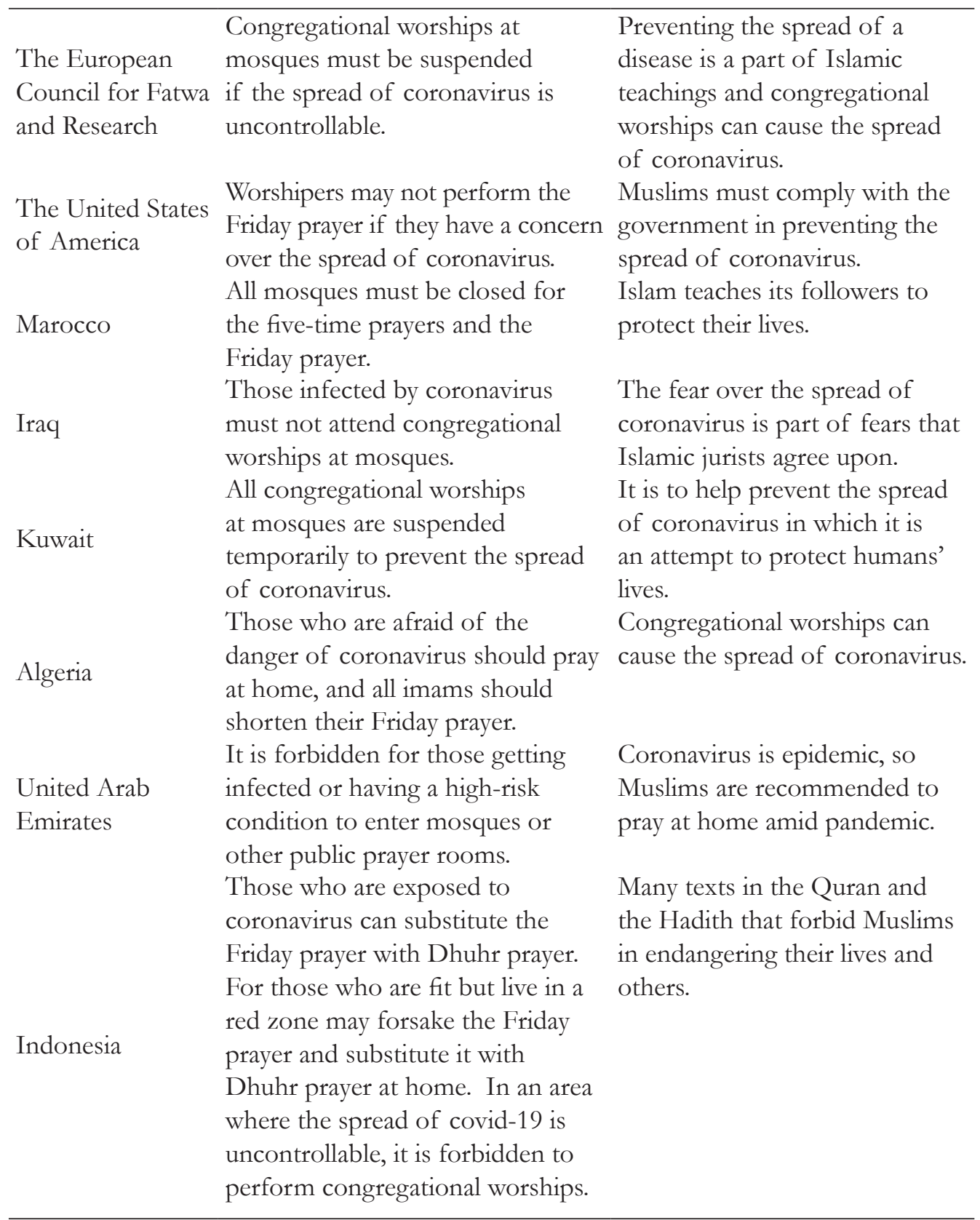




\section{Pros and cons regarding the fatwas of the covid-19}

Fatwas around the covid-19 pandemic have received multiple responses, in which some of them are positive while the others are negative. In Indonesia, these fatwas were supported by prominent Islamic organizations such as Muhammadiyah, Nahdlatul Ulama, and Persatuan Islam. These organizations issued official statements which amplified fatwas issued by the Indonesian Ulama Council. For instance, Muhammadiyah issued an official statement number 02/EDR/I.0/E/2020 dated on March 24 ${ }^{\text {th }}, 2020$, about a guidance for performing worships during the covid-19 pandemic. Meanwhile, Nahdlatul Ulama produced several recommendations on how to conduct the Friday prayer in areas that had been exposed to the covid-19 on March 19 ${ }^{\text {th }}$, 2020. In addition, Persatuan Islam issued a statement on how to anticipate the spread of coronavirus on March 21 ${ }^{\text {st }}, 2020$.

Resistance towards the fatwas emerged in which the oppositions mostly questioned the legal arguments behind the fatwas. These oppositions were individuals such as the Judge Al-Mutairi from Kuwait, Sheikh Muhammad Saleem Al-Daw from Mauritania, and Jedi Abdul Kadir from Algeria (Sabary, 2020). In Indonesia, several ulama also opposed fatwas about the covid-19 such as Muhammad Najih Maemoen and Mustain Syafi'i.

Several aspects that were questioned by these oppositions include the generalization of the law, legal sources that were used, the validity of methodology that was employed in drawing fatwas, and the role of ulama as the authority in determining fatwas. According to these oppositions, the transmission level of coronavirus from one area to other areas was different. In other words, there were red areas with many cases of coronavirus while there were also green areas where cases were barely found. As such, fatwas which banned congregational worships should only be implemented in red areas, in which the operative cause for such fatwas was apparent.

Additionally, these oppositions also considered the selection of legal sources regarding pandemic as biased. They argued that legal sources with regard to worships were substantially overlooked. They added that scriptural texts which explained the holiness of mosques, the procedure for forsaking congregational worships, and the procedure for substituting the Friday prayer with Dhuhr prayer at home were not taken into account proportionally (Sabary, 2020). For example, a fatwa which regulated that all Muslims,legardless their healthy 
condition, were forbidden to perform congregational worships at mosques contradicted the Hadith about those who were allowed to forsake them.

In terms of methodology, those who proposed the fatwas regarding the covid-19 employed maslahah (public interests) as the rationale of their proposal. They contended that the principle of avoiding dangers as more important than pursuing benefits must be emphasized. 'Danger' and 'benefit' should be evaluated proportionally based on realities. The 'danger' of coronavirus was ambivalent in terms of its different levels of danger in one area to another. Meanwhile, the 'benefit' for performing congregational worships was evident and was similar in different areas. In this context, prioritizing the 'danger' over the 'benefit' in determining the fatwas regarding the covid-19 was considered as methodologically invalid.

Another opposing argument against the fatwas of covid-19 focuses on the issue of authority. The oppositions questioned how the basis of the fatwas, which was the danger of coronavirus, was derived from health experts' sources. In the hierarchy of Islamic law, medical authority is categorized into secondary legal sources since these sources are the product of humans' logic. The legal arguments in the fatwas showed a discordance between the God's authority and men's authority. Specifically, God has ordered Muslims to perform congregational worships at mosques, while medical doctors have recommended that congregational worships be suspended.

\section{Science as 'illah (reason) in the fatwas of the covid-19}

In determining the fatwas regarding the covid-19, ulama employed an istigrâ (inductive) model, in which they departed from realities and made decisions over these realities. Realities in this case were anything related to the covid-19 pandemic, which endangered the lives of people around the world. Medical findings were considered as adequate legal sources which indicated that coronavirus posed a definite danger, disrupting public lives, and in accordance with objective of shariah.

The danger of coronavirus has been scientifically proven. Initially found in Hubei, China in December 2019, the virus has spread beyond China and infected more 1,2 million people in 184 countries within a period of three months. The World Health Organization 
(WHO) officially stated the spread of coronavirus as the world pandemic on March $11^{\text {th }}$, 2020 (Gennaro \& Pizzol, 2020). The average positivity rate of people getting a coronavirus is 5,1\% worldwide (Read, 2020). Additionally, the epidemic and biological characteristics of coronavirus are unusual which make this virus spread more rapidly than other known viruses (Meo \& Alhowikan, 2020). Furthermore, this virus mutates rapidly, changes tropism tissue, overrides genus barriers, and adapts to any epidemiological situations (Helmy et al., 2020).

From a biological perspective, coronavirus is a single stranded RNA virus which looks like a crown wrapped with glycoprotein (Gennaro \& Pizzol, 2020). Its size is microscopic with average diameters of 65 to $125 \mathrm{~nm}$ (Shereen \& Khan, 2020). The average incubation periods of this virus are 2 to 14 days and the average age of people infected by this virus is 59 (Meo \& Alhowikan, 2020). Symptom period to mortality period ranges from 6 to 41 days with an average of 14 days, depending on the patient's immune system (Hamid, S., Mir \& Rohela, 2020). Patient's condition is usually at the worst stage within 7 to 14 days after getting infected (Gennaro \& Pizzol, 2020). This virus specifically attacks the lungs which causes severe breathing dysfunction and fatality (Shereen \& Khan, 2020).

A high coronavirus death rate is an indication that this virus is dangerous and substantially disrupts public lives. According to pathophysiology, the virus transmits through a physical contact, droplets, orofecal route, and vomit of those infected by the virus during the incubation period (Helmy et al., 2020). The virus sticks to dry surface, mucous membrane, eyes, and mouth (Kampf, 2020). The more people get infected means that the virus spread more widely (Hamid, S., Mir \& Rohela, 2020). As such, some preventive measures to prevent the spread of coronavirus include social distancing, wearing face masks, covering coughs and sneezes, washing hands with soaps, and keeping unwashed hands away from the face (Gennaro \& Pizzol, 2020).

The covid-19 pandemic has caused not only health crisis but also humanitarian crisis and economic disruptions. Additionally, informal sectors were also affected by this pandemic in which the jobless number reached 195 million globally (Amri et al., 2020). This pandemic has forced governments in many countries to deal with a complex situation in which they were often left with only two options, namely saving the lives of their people or the economy of their countries (i.e., livelihoods). Another apparent impact of this 
pandemic was on people's social behaviours. Many people became weary and confused of the situation, lost their trust in their governments, and felt discriminated, stigmatized, and rejected (Ennis et al., 2020). Social pressures felt by many covid patients and health workers (Ennis et al., 2020) as well as the expensive cost for the covid-19 treatment (Shidiq, 2020, p. 8) were noticeable problems caused by this pandemic.

The apparent danger of coronavirus and its rapid spread become the rationale for taking preventive measures against this virus. Human-to-human contact is the main cause of the spread; thus, mass gatherings should be temporarily banned to minimize the virus transmission from one person to another. As such, congregational worships should also be suspended temporarily as these involve gathering people in a common space, namely mosque. Ulama formulate fatwas regarding the covid-19 pandemic by comparing and contrasting scriptural texts, namely the Quran and the Hadith, and empirical studies from scientists. During the formulation process, ulama attempt to accommodate these two ontologically different sources fairly. To this extent, scriptural texts that regulate worships are considered as general propositions while scientific findings are considered as specific propositions. The danger of coronavirus become the rationale for reconceptualizing the general propositions of religious laws. In the Islamic legal method, this reconceptualization is known as sad azं-zarîah (blocking the means), that is reconceptualizing a law to prevent destructions and assuring public safety (Auda, 2008).

Fatwas about the suspension of congregational worships, for example, are supported by texts in the Quran, the Hadith, ulama's consensus, and legal maxim. This indicates that ulama have interpreted the scriptural texts contextually, in which the contextualization is in congruent with the objectives of Islam, namely actualizing benefits for all people. These benefits include five kinds of protections, which are the protection of religion, lives, minds, lineage, and wealth (Auda, 2008). Based on this argument, the suspension of congregational worships is legally justified or in line with the principles and objective of Islamic laws.

Avoiding the danger of coronavirus is the primary argument behind the formulation of the aforementioned fatwas. In the principles of Islamic jurisprudence, preventive measures over dangerous situations must be prioritized (Al-Suyuti, n.d.). In this case, these preventive measures are valid reason for reconceptualizing laws. The rapid spread of coronavirus 
likely occurs when there are mass gatherings, that is through a human-to-human contact. Congregational worships potentially cause the rapid transmission of coronavirus since many people gather in one place and likely make a physical contact one another. Thus, such gatherings should be prevented although these are parts of religious activities. In other words, the fatwas do not forbid Muslims from performing worships, but these particularly restrict the way worships are performed collectively due to the pandemic.

The preventive measures over coronavirus are aimed at preserving humans' lives, in which this protection is considered as essential (darury). On the other hand, prayers are also essential as the purpose of prayers is to preserve faith. However, the way prayers are performed collectively at mosques is not considered as essential but secondary (bajiy). In this context, the levels of necessity between protecting lives and performing congregational worships are different. That is, essential practices must be prioritized over secondary practices (Asy-Syatibi, 1997). Embarking on this principle, ulama have decided to suspend congregational worships at mosques to protect the lives of people amid the covid-19 pandemic.

The legal decisions in the fatwas regarding the restriction of performing congregational worships at mosques are methodologically valid. These fatwas are aimed at realizing one of the main objectives of sharia, namely protecting humans' lives. The definite danger of coronavirus as concluded in authoritative medical and empirical studies meets the legal operative cause. Particularly, coronavirus is dangerous because not only it infects an individual but also it infects people around the world rapidly and endangers their lives. In these fatwas, ulama demonstrate their capacity in responding to the pandemic and educating their followers. Additionally, these fatwas show that ulama acknowledge science and use scientific findings to help them interpret religious texts. The use of science as a means to help interpret religious texts indicates a dynamic and reformative practice of Islamic laws.

\section{Revelation and science: between the god's authority vis a vis men's authority}

The relationship between religion and science in fatwas regarding the covid-19 encompasses a doctrinal-philosophical dimension and a legal-ethic dimension. Science is characterized as relative, dynamic, and flexible, while scriptural texts are absolute, static, and permanent. 
Doctrinally, congregational worships are highly recommended, and these are beneficial for Muslims. On the other hand, the covid-19 pandemic poses a danger for those performing congregational worships at mosques. It is evident that there is a contradiction between these two perspectives. In fatwas regarding the covid-19 pandemic, the danger of the pandemic outweighs the benefit of performing congregational prayers. That is, science is employed as the main reference for interpreting and determining religious laws.

Through fatwas regarding the covid-19 pandemic, ulama, with their authority, integrate revelation and science without disregarding the role of God as an absolute truth in Islam. The God's authority is represented through scriptural texts. With this understanding, ulama and Islamic jurists play an important role in interpreting and implementing scriptural texts in real life. In other words, there is an integration between the God's authority (the absolute source of laws) and men's authority (the interpreter of the scriptural texts). The adaptability, flexibility, dynamic, and plurality of Islamic laws indicate the agency of ulama in elaborating laws that are created by God (Hallaq, 2009).

In a legal-ethic dimension, science becomes the primary consideration for suspending congregational worships at mosques. From a legal aspect, the status of congregational worships at mosques is sunnah (noncompulsory) and its benefit level is secondary. On the other hand, the danger and the rapid spread of coronavirus through congregational worships are evident and thus suspending them is considered as essential. In this context, ulama have decided to use scientific findings as the basis for reconceptualizing laws related to congregational worships. From a methodological aspect, there has been a shift in thinking models (ijtihad), that is from a deductive model (istidlâl) to an inductive model (istiqrâ). In addition, a liberal utilitarian theory is emphasized, in which the role of logic is more dominant than scriptural texts (Zabidi, 2012). In case of the covid-19 pandemic, ulama do not interpret scriptural texts normatively. Instead, they depart from scientific findings which conclude the danger of coronavirus. These scientific findings are then correlated with religious principles which discuss about the necessity to avoid dangers. In other words, texts in the Quran and the Hadith are used to justify scientific recommendations, in which congregational worships at mosques must be temporarily banned due to the danger and the spread of coronavirus. 
The shift from a deductive to an inductive thinking model indicates the dominant role of ulama in deciding fatwas. An inductive model emphasizes the use of logic over scriptural texts and is usually employed against a specific reality. In this case, the legal product of this model cannot be implemented universally and is fluid depending on the similarity of a reality from one context to another one. In particular, an inductive model highlights the use of logic in interpreting normative texts by expanding, developing, and limiting their textual meanings. In other words, an inductive model does not overlook normative or scriptural texts, but it provides contextual interpretations regarding the texts. Thus, the integration between scientific findings and contextual interpretations of scriptural texts provides more comprehensive and coherent fatwas about the covid-19 pandemic.

In deciding the fatwas, ulama have implemented an epistemological integration through two dimensions, namely a productive and a consumptive dimension (Malkawi, 2015). A productive dimension is reflected in the form of intellectual creativity, that is the use of an inductive model in deciding a law. This model does not consider only a theoretical aspect but also a mental-psychological aspect in overcoming social problems. People's psychological state regarding their fears of getting infected by coronavirus is taken into account in this model. On the other hand, a consumptive dimension is reflected in the use of an intellectual structure in understanding the phenomenon of coronavirus. Scriptural texts are considered as an open book that can be interpreted subjectively, while scientific findings are thought to be objective and can be used to give specific meanings to scriptural texts. In other words, religious doctrines, which belong to the God's authority, can be interpreted through the lens of scientific findings, which are related to men's authority.

From an axiological point of view, science helps to realize the objectives of Islam in relation to mankind, that is to protect and preserve humans' lives. It is in line with a tawhidi methodology, which combines a scientific method, mainly based on empirical studies, and a religious method, mainly based on interpretations. Ethically, this methodology includes such aspects as justice, integrity, and objectivity (Malkawi, 2015). As such, fatwas which restrict congregational worships amid the pandemic are the result of ulama's careful thinking in explaining the covid-19 phenomenon based on their perceptions, scientific analysis, and interpretations towards scriptural texts. 
The consideration of science in deciding fatwas about the covid-19 pandemic indicates the acknowledgement of logic in Islamic laws. Benefits and dangers are scrutinized carefully, while scriptural texts and realities are interpreted comprehensively. Texts in the scriptures are static and require humans' interpretations to make them applicable laws (Hillier, 2010). A harmony between revelation and logic occurs during the interpreting process. That is, revelation reflects a belief aspect while logic illustrates a knowledge aspect (Gallegos, 2006). Islamic laws, as reflected in fatwas about the covid-19 pandemic, are formed through integrating belief (divine law) and knowledge (human made law).

\section{Conclusion}

Religion and science pose ontological, epistemological, and axiological differences. Despite these differences, the two can be combined through a methodological integration. This integration is reflected in the fatwas regarding congregational worships amid the covid-19 pandemic. As reflected in the fatwas, ulama have attempted to correlate revelation and logic, or the God's authority and men's authority. The purpose of this correlation is to realize the main objective of Islamic sharia, which is to protect mankind and the world. In current contexts, the use of functional paradigm to understand the dialectic between revelation, logic, and realities is needed. Thinking models used when ulama issue fatwas should be studied. It is to evaluate whether the fatwas are adaptable and contextual to current situations. Fatwas cannot be viewed as a static legal product, but they should become a legal source which poses a social engineering function.

\section{Bibliography}

Abdullah, M. A. (2014). Religion, Science and Culture, an Integrated, Interconnected Paradigm of Science. Al-Jami'ah: Journal of Islamic Studies, 52(1), 175-203.

Al-Kahtani, T., Aljerian, K., Golding, B., \& Alqahtani, S. (2015). Forensic science in the context of Islamic law: A review. Journal of Forensic and Legal Medicine, 34, 179-181.

Al-Suyuti. (n.d.). Al-Asybah wa an-Nazair. Dar al-Fikr.

Amri, P., Roesad, K., \& Damuri, Y. R. (2020, April). How Can COVID-19 Enhance Our Environmental Commitments? CSIS Commentaries. 
Science-based ljtihad: religious and scientific dialectic on fatwas regarding...(Ali Sodiqin)

Arion, A.-C. (2018). Relationship Between Faith and Science in The Major World Religions. IFIJISR Icoana Redintei, 4(7), 51-66.

Asy-Syatibi, Ibrahim bin Musa. (1997). Al-Muwafaqat. Cet.1. Tahqiq: Masyhur Hasan Salman Daru Ibni Affan.

Arsyad, A. (2016). Integration Tree and the Interconnectivity of Science and Religion. Kalimah: Jurnal Studi Agama Dan Pemikiran Islam, 14(2), 115-138.

Auda, J. (2008). Maqasid Al-Shariah As Philosophy of Islamic Law, A Systems Approach. The International Institute of Islamic Thought.

Az-Zuhaili, W. (2013). Usul al-Fiqh al-Islâmy (Jilid I \&). Dar al-Fikr al-Mu'ashir.

Bagir, Z. A. (2005). Integrasi Ilmu dan Agama, Interpretasi dan Aksi (Z. A. Bagir (ed.)). Mizan.

Baihaki, E. S. (2018). Preacher and Scientist: Integration of Science in Law Determination. Kaunia, 14(1), 1-4.

Barbour, I. G. (2002). Juru Bicara Tuhan Antara Sains dan Agama (diterjemah). Mizan.

Ebrahim, S. H., \& Memish, Z. A. (2020). Saudi Arabia`s Measures to Curb the COVID-19 Outbreak: Temporary Suspension of the Umrah Pilgrimage. Journal of Travel Medicine, 27(3).

Ennis, M. C., McMillan, \& Hedges, K. (2020). Pandemic Perspectives: Responding to COVID-19. Open Anthropology, 8(1).

Galadari, A. (2011). Science vs. Religion: The Debate Ends. The International Journal of Science in Society, 2(2), 1-9.

Gallegos, E. (2006). Reason in Islamic Law. Macalester Islam Journal, 1(1), 48-53.

Gennaro, F. Di, \& Pizzol, D. (2020). Coronavirus Diseases (COVID-19): Current Status and Future Perspectives: A Narrative Review. International Journal of Environmental Research and Public Health, 17(2690), 1-11.

Guessoum, N. (2014). Islam dan Sains Modern (Terjemahan). Mizan.

Hallaq, W. B. (2009). An Introduction to Islamic Law. Cambridge University Press.

Hamid, S., Mir, M. Y., \& Rohela, G. K. (2020). Novel coronavirus disease (COVID-19): a pandemic (epidemiology, pathogenesis and potential therapeutics). New Microbes and New Infections, 35(100679), 1-10. 
Ijtihad: Jurnal Wacana Hukum Islam dan Kemanusiaan, Volume 21, No. 1, Juni 2021: 79-97

Haught, J. F. (2004). Perjumpaan Sains dan Agama Dari Konflik ke Dialog (translated). Mizan. Helmy, Y., Fawzy, M., \& Elaswad. (2020). The COVID-19 Pandemic: A Comprehensive Review of Taxonomy, Genetics, Epidemiology, Diagnosis, Treatment, and Control. Journal of Clinical Medicine, 9(1225), 1-30.

Hillier, H. C. (2010). Muhammad Iqbal on al-fiqh: Towards a Natural Law Jurisprudence. Journal of Islamic Law and Culture, 12(3), 258-283.

Indriya, I. (2020). Konsep Tafakkur Dalam Alquran Dalam Menyikapi Coronavirus Covid-19. SAL AM: Jurnal Sosial Dan Budaya Syar-I, 7(3), 211-216.

Kampf, G. (2020). Persistence of Coronaviruses On Inanimate Surfaces and their Inactivation with Biocidal Agents. Journal of Hospital Infection, 104, 246-251.

Malkawi, F. H. (2015). Epistemological Integration, Essentials of an Islamic Methodology (Translated). International Institute of Islamic Thought.

Meo, S. A., \& Alhowikan, A. M. (2020). Novel Coronavirus 2019-ncov: Prevalence, Biological and Clinical Characteristics Comparison with SARS-CoV and MERS-CoV. European Review for Medical and Pharmacological Sciences, 24, 2012-2019.

Mufid, F. (2014). Islamic Sciences Integration. QIJIS: Qudus International Journal of Islamic Studies, 2(2), 144-160.

MUI. (2020). Fatwa Majelis Ulama Indonesia Nomor: 14 tahun 2020 tentang Penyelenggaran Ibadah Dalam Situasi Terjadi Wabah Covid-19. Majelis Ulama Indonesia. https://mui.or.id/ category/produk/fatwa/

Mustaqim, A. (2010). Epistemologi Tafsir Kontemporer (1st ed.). LKiS.

Parish, H. (2020). The Absence of Presence and the Presence of Absence: Social Distancing, Sacraments, and the Virtual Religious Community during the COVID-19 Pandemic. Religions, 11(276), 1-13.

Qudsy, S. Z., \& Sholahuddin, A. (2020). Kredibilitas Hadis dalam COVID-19: Studi atas Bazl al-Ma'un fi Fadhli al-Thaun karya Ibnu Hajar al-Asqalany. Al Quds Jurnal Studi Alquran Dan Hadis, 4(1), 1-18.

Read, Jonathan \& Bridgen, Jessica \& Cummings, Derek \& Ho, Antonia \& Jewell, Chris. (2020). Novel Coronavirus 2019-Ncov: Early Estimation Of Epidemiological Parameters And Epidemic Predictions. 
Science-based ljtihad: religious and scientific dialectic on fatwas regarding...(Ali Sodiqin)

Rolston, H. (1987). Science and Religion A Critical Survey. Random House.

Sabary, M. (2020). Fatawa al-Ulama Hawla Virus Kuruna. Dâr al-Basyîr.

Sanda, D. C., Alexandra, L., Smarandoiu, \& Munteanu, C. (2017). The Dialogue between Science and Religion: A Taxonomic Contribution. Religions, 8(35), 1-18.

Shereen, M. A., \& Khan, S. (2020). COVID-19 Infection: Origin, Transmission, and Characteristics of Human Coronaviruses. Journal of Advanced Research, 24, 91-98.

Shidiq, A. R. (2020, April 8). Our Health System Capacity Vs The Demand From A LargeScale Social Distancing Policy. CSIS Commentaries.

Sholeh, M. A. N. (2020). Towards a Progressive Fatwa: MUI's Response to the COVID-19 Pandemic. Abkam, 20(2), 281-298.

Syukriya, A. J., \& Faridah, H. D. (2019). Kajian Ilmiah dan Teknologi Sebab Larangan Suatu Makanan Dalam Syariat Islam. Journal of Halal Product and Research, 2(1), 44-50.

Tahir, A. H. (2015). Ijtihad Maqasidi, Rekonstruksi Hukum Islam berbasis Interkoneksitas Maslahah. LKiS.

Zabidi, A. Z. (2012). Paradigma Utilitarianistik dalam Istimbath Hukum Islam. Ihkam, 7(3), 368-382. 
